\title{
Laporan kasus berbasis bukti Reaksi Hipersensitivitas Terhadap Pegylated Asparaginase Dibandingkan L-asparaginase pada Anak dengan Leukemia Limfoblastik Akut
}

\author{
Miranti Fristy Medyatama, Murti Andriastuti \\ Departemen Ilmu Kesehatan Anak Fakultas Kedokteran Universitas Indonesia Rumah Sakit Dr Cipto Mangunkusumo, Jakarta
}

Latar belakang. L-asparaginase (L-asp) adalah regimen kemoterapi utama dalam terapi LLA pada anak. Kejadian reaksi hipersensitivitas akibat L-asp sangat tinggi, menyebabkan terapi tidak dapat dilanjutkan dan memengaruhi angka kesintasan. Dibutuhkan sediaan lain yang lebih hipoalergenik untuk dapat menggantikan L-asp.

Tujuan. Melakukan telaah kritis untuk membandingkan reaksi hipersensitivitas dan efektivitas antara PEG-asp dan L-asp pada pasien anak dengan LLA.

Metode. Pencarian artikel dilakukan secara daring menggunakan instrumen kata kunci yang sesuai melalui basis data Pubmed, Cochrane dan Google Scholar pada bulan Febaruari 2021.

Hasil. Didapatkan 3 artikel berupa meta-analisis, uji klinis acak dan kohort retrospektif. Reaksi hipersensitivitas dengan L-asp adalah 30 $41 \%$, sedangkan dengan PEG-asp 13-14\% ( $<<0,05)$. Tidak terdapat perbedaan bermakna terhadap angka remisi maupun angka kesintasan antara penggunaan PEG-asp dan L-asp ( $>00,005)$.

Kesimpulan. PEG-asp dapat menurunkan angka kejadian reaksi hipersensitivitas dan memiliki efektivitas yang sama dengan L-asp. Sari Pediatri 2022;23(5):336-45

Kata kunci: PEG-asparaginase, E. coli L-asparaginase, leukemia limfoblastik akut pada anak

\section{Evidence base case report \\ Hypersensitivity Reactions Associated with Pegylated Asparaginase Versus L-Asparaginase in Children with Acute Lymphoblastic Leukemia}

Miranti Fristy Medyatama, Murti Andriastuti

Background. L-asparaginase (L-asp) is an essential component of therapy for ALL in children. Despite the widespread success of asparaginase as part of multi-agent chemotherapy, hypersensitivity remains a significant problem, often requiring the termination of asparaginase and affect the outcome. Other preparations that are more hypoallergenic are needed to replace L-asp.

Objective. To conduct a critical study to compare the hypersensitivity rate and efficacy of of PEG-asp with L-asp in children with ALL.

Methods. Searching for articles was done online using appropriate keywords through Pubmed, Cochrane and Google Scholar databases in February 2021.

Result. Three articles were obtain in the form meta-analysis, randomized control trial and cohort studies. Hypersensitivity rate were lower in the PEG-asp group $(30-40 \%$ vs $13-14 \%, \mathrm{p}<0.05)$. There were no signifificant difffferences in complete remission rate and efent free survival between the PEG-asp and L-asp group (all P>0.05).

Conclusion. PEG-asp group had a lower hypersensitivity rate and was similarly efficacious compare to L-asp group. Sari Pediatri 2022;23(5):336-45

Keywords: PEG-asparaginase, E. coli L-asparaginase, childhood acute lymphoblastic leukemia

Alamat korespondensi: Murti Andriastuti. Departemen Ilmu Kesehatan Anak FKUI/RSCM. Jl. Salemba Raya No. 6, Jakarta Pusat 10430. Email: murtiandri@yahoo.com 
L eukemia limfoblastik akut (LLA) merupakan jenis leukemia yang paling sering ditemukan pada anak. Di antara jenis keganasan pada anak, LLA menempati urutan teratas, yaitu antara $25-35 \%$. Secara klinis, LLA terbagi menjadi risiko tinggi (RT) dan biasa (RB). Awalnya, LLA termasuk penyakit dengan mortalitas yang tinggi, tetapi dengan kemajuan dalam bidang kedokteran, terutama mengenai diagnosis dan tata laksana, angka kesintasan atau event free survival (EFS) LLA di negara maju terus meningkat mencapai lebih dari 90\%.,Angka ini sangat berbeda dibandingkan dengan negara berkembang. Penelitian di Indonesia yang pernah dilakukan di Jakarta dan Yogyakarta mendapatkan EFS LLA pada anak antara $52-73 \%$. $^{3}$

Kombinasi beberapa regimen kemoterapi terbukti dapat meningkatkan angka kesintasan pasien anak dengan LLA., L-asparaginase (L-asp) adalah suatu enzim yang diisolasi dari Escherichia coli (E. coli) dan menjadi salah satu regimen kemoterapi utama dalam pengobatan LLA. Sel blas membutuhkan sumber asparagin eksogen untuk pertumbuhan sel. Enzim L-asp menghidrolisis asparagin sehingga deplesi asparagin secara efektif menyebabkan inhibisi sintesis protein sel blas. ${ }^{5}$ Namun, karena berasal dari protein bakteri maka L-asp dapat menyebabkan reaksi hipersensitivitas dan inaktivasi akibat terbentuknya antibodi anti-asparaginase. Angka kejadian reaksi hipersensitivitas terhadap L-asp adalah $30-70 \%{ }^{6}$

Enzim L-asp dapat diberikan secara intramuskular (IM)/subkutan (SK) atau intravaskular (IV). Untuk mengurangi risiko reaksi hipersensitivitas direkomendasikan pemberian secara IM/SK. Namun, pemberian secara IM/SK menimbulkan rasa nyeri, bila membutuhkan dosis yang besar maka penyuntikan harus dilakukan berulang di sisi yang berbeda dan menyebabkan trauma pada pasien dan keluarga. Pemberian premedikasi dengan steroid atau antihistmin dikatakan hanya mencegah reaksi klinis, tetapi tidak dapat mencegah netralisasi enzim yang dapat menyebabkan obat menjadi tidak efektif. Untuk mengatasi hal tersebut, saat ini terdapat sediaan pegylated asparaginase PEG-asp, yaitu konjugasi polyethylene glycol (PEG) ke L-asp E. coli. Konjugasi PEG diharapkan dapat menurunkan potensi imunogenik dari L-asp sehingga dapat menurunkan risiko terjadinya reaksi hipersensitivitas. ${ }^{5,7}$

Di beberapa negara maju PEG-asp sudah digunakan sebagai lini pertama yang menggantikan L-asp. Namun, di Indonesia saat ini masih menggunakan sediaan L-asp. Tujuan dari laporan kasus berbasis bukti ini adalah untuk membandingkan reaksi hipersensitivitas dan efektivitas antara PEG-asp dan L-asp pada anak yang terdiagnosis LLA. Hasil dari laporan kasus berbasis bukti ini diharapkan dapat dijadikan bahan pertimbangan untuk protokol pengobatan LLA pada anak di Indonesia.

\section{Ilustrasi kasus}

Pasien anak perempuan, usia empat tahun satu bulan, nomor rekam medis (NRM) 4317596, masuk perawatan untuk melanjutkan kemoterapi LLA RT dengan riwayat alergi terhadap L-asp. Pasien sebelumnya sudah pernah menjalani kemoterapi LLA RB saat usia satu tahun, sudah menyelesaikan protokol kemoterapi selama dua tahun dan dinyatakan remisi pada Oktober 2020. Pada bulan Desember 2020, pasien kembali masuk perawatan dengan keluhan demam, nyeri tulang, terdapat anemia, trombositopenia, leukopenia dan di darah tepi ditemukan sel blas 5\%. Pasien kemudian menjalankan pemeriksaan aspirasi sumsum tulang dan didapatkan hasil sesuai dengan LLA relaps.

Pada bulan Januari 2021, pasien memulai kemoterapi protokol LLA RT. Saat pemberian L-asp pertama secara subkutan dengan dosis $7500 \mathrm{IU} / \mathrm{m} 2$, timbul reaksi alergi berupa bengkak pada wajah dan bibir disertai kulit kemerahan yang terjadi secara tiba-tiba dalam waktu 15 menit setelah penyuntikan. Keluhan disertai rasa mual dan muntah. Tidak ada sesak napas, pusing atau gatal. Pada pemeriksaan fisis tekanan darah 89/51

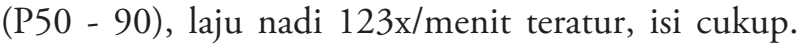
Akral teraba hangat dan waktu pengisian kapiler kurang dari dua detik. Tampak angioedema di regio wajah. Pasien kemudian diberikan epinefrin IM dilanjutkan difenhidramin IV hingga gejala menghilang.

Untuk melanjutkan protokol kemoterapi dan mengatasi alergi terhadap L-asp maka pasien diberikan L-asp dengan diberikan premedikasi. Pemberian terapi dilakukan di rawat inap untuk memantau reaksi hipersensitivitas yang mungkin terjadi.

\section{Pertanyaan klinis}

Berdasarkan ilustrasi kasus di atas, terdapat pertanyaan 
Tabel 1. Penyusunan PICO

\begin{tabular}{lccc}
\hline $\begin{array}{l}\text { Populasi } \\
(\mathrm{P})\end{array}$ & $\begin{array}{c}\text { Intervensi } \\
(\mathrm{I})\end{array}$ & $\begin{array}{c}\text { Pembanding } \\
(\mathrm{C})\end{array}$ & Hasil (O) \\
\hline Pasien & PEG-asp & L-asp & $\begin{array}{c}\text { Angka } \\
\text { anak }\end{array}$ \\
dengan & & & $\begin{array}{c}\text { kejadian reaksi } \\
\text { hipersensitivitas }\end{array}$ \\
LLA & & & \\
\hline
\end{tabular}

klinis sebagai berikut, pada pasien anak dengan LLA, apakah pemberian PEG-asp dapat menurunkan angka kejadian reaksi hipersensitivitas dibandingkan dengan pemberian L-asp?

\section{Metode penelusuran literatur}

Untuk menjawab masalah tersebut dilakukan penelusuran pustaka secara daring dengan mempergunakan instrumen pencari PubMed, Cochrane dan Google Scholar pada bulan Februari 2021. Kata kunci yang digunakan adalah "polyethylene glycol conjugated asparaginase", "pegaspargase", "PEG-asp", "Escherichia coli L-asparaginase", "E. coli L-asp", "childhood acute lymphoblastic leukemia", dan "ALL" (Tabel 2). Setelah artikel didapatkan, dilakukan seleksi dengan kriteria inklusi, yaitu bahasa pengantar adalah bahasa Inggris, publikasi dalam rentang waktu sepuluh tahun terakhir, serta penelitian berupa uji klinis, kohort, studi komparatif, meta-analisis, dan telaah sistematik. Kriteria eksklusi meliputi artikel tanpa fulltext, artikel ganda dan tidak melibatkan populasi anak sebagai sampel penelitian (Gambar 1). Setelah melalui proses seleksi, terdapat tiga artikel yang dipilih dan ditelaah dengan memperhatikan validitas, kepentingan, dan penerapan pada pasien (Tabel 3). Levels of evidence ditentukan berdasarkan klasifikasi yang dikeluarkan oleh Oxford for evidence-based medicine untuk uji terapi.

\section{Hasil penelusuran literatur}

Penelusuran artikel dilakukan melalui berbagai pangkalan data dengan kriteria inklusi studi pada pasien anak dengan LLA yang membandingkan PEG-asp dan L-asp. Luaran yang dinilai adalah reaksi hipersensitivitas. Strategi pencarian menghasilkan tiga artikel bermanfaat yang relevan terhadap pertanyaan klinis dengan alur pada Gambar 1. Sebanyak tiga studi yang bermanfaat dalam menjawab pertanyaan klinis adalah studi metaanalisis oleh Dai dkk pada tahun 2020, studi kohort oleh Liu dkk pada tahun 2019. dan uji klinis oleh Place dkk pada tahun 2015.

Studi pertama adalah studi meta-analisis oleh Dai $\mathrm{dkk}^{10}$ yang dilakukan pada populasi anak dengan LLA di China pada tahun 2020. Meta-analisis dari 15 studi yang dipublikasi di China dengan total 1194 pasien. Studi ini mecari literatur di berbagai pangkalan data terutama di China dengan kriteria inklusi adalah semua studi klinis acak pada anak China usia 0-18 tahun yang mendapat PEG-asp sebagai kelompok eksperimen dan L-asp sebagai kelompok kontrol. Kedua sediaan obat diberikan secara IM sesuai rekomendasi Chinese Guideline for the Diagnosis and Management of Children with ALL. Tujuan primer studi ini adalah mengetahui efikasi PEG-asp dibandingkan L-asp dengan menilai angka remisi komplit (CR) dan overall response rate (ORR). Tujuan sekunder studi adalah keamanan PEGasp dibandingkan L-asp yang dinilai adalah kejadian reaksi hipersensitivitas, gangguan fungsi hati, gejala gastrointestinal dan gangguan koagulopati. Studi dengan populasi yang memiliki komplikasi berat seperti infeksi paru atau penyakit lain seperti diabetes akan di eksklusi.

Dai dkk ${ }^{10}$ mendapatkan bahwa tidak ada perbedaan bermakna untuk CR dan ORR pada kedua kelompok ( $>0,05)$. Terdapat empat studi (239 pasien) yang melaporkan angka kejadian hipersensitivitas. Pada kelompok yang mendapatkan PEG-asp kejadian hipersensitivitas lebih rendah dengan nilai $\mathrm{RR}=0,45$, interval kepercayaan (IK) 95\%: 0,27 - 0,75 dan nilai $\mathrm{p}=0,02$. Heterogenitas tidak bermakna berdasarkan uji kai kuadrat dan $I^{2}$. Studi ini juga menilai luaran tambahan terkait lama waktu rawat dan frekuensi kunjungan ke rumah sakit. Pemberian PEG-asp setiap dua minggu sekali sedangkan L-asp diberikan 2-3 kali seminggu sehingga secara signifikan frekuensi kunjungan dan lama rawat pada kelompok PEG-asp lebih rendah dibandingkan kelompok L-asp.

Terdapat beberapa kekurangan pada studi metaanalisis oleh Dai dkk. ${ }^{10}$ Pertama, studi yang dimasukkan semua dipublikasi di China dengan skala kecil. Kedua, penilaian risiko bias menggunakan Cohrane recommendation tool menunjukkan adanya $3 / 15$ studi dengan risiko bias yang tinggi terkait kurangnya informasi mengenai metode yang digunakan. Selain itu, Egger's test untuk menilai bias publikasi juga menunjukkan adanya bias ( $\mathrm{p}=0,03$, IK 95\% 0,82-1,44). 
Tabel 2. Strategi pencarian yang dilakukan melalui PubMed, Cochrane, dan Google scholar

\begin{tabular}{|c|c|c|c|}
\hline $\begin{array}{l}\text { Portal } \\
\text { pencarian }\end{array}$ & Kata kunci & $\begin{array}{c}\text { Artikel yang } \\
\text { didapat }\end{array}$ & $\begin{array}{c}\text { Artikel yang } \\
\text { relevan }\end{array}$ \\
\hline Pubmed & $\begin{array}{l}\text { ((PEG-asp OR pegylated asparaginase OR pegylated (PEG)-ASP OR } \\
\text { polyethylene glycol conjugated asparaginase OR pegaspargase) AND } \\
\text { (Escherichia coli L-asparaginase OR E. coli L-asp OR native L-asparaginase } \\
\text { (L-asp)) AND (hypersensitivity OR allergic reactions) AND (childhood } \\
\text { acute lymphoblastic leukemia)) }\end{array}$ & 19 & 2 \\
\hline Cochrane & $\begin{array}{l}\text { "PEG-asp" OR "pegylated asparaginase" OR "pegylated (PEG)-ASP” OR } \\
\text { "polyethylene glycol conjugated asparaginase" OR "pegaspargase" AND } \\
\text { "Escherichia coli L-asparaginase OR E. coli L-asp" OR "native L-asparaginase } \\
\text { (L-asp)" AND "hypersensitivity" OR “allergic reactions" AND "childhood } \\
\text { acute lymphoblastic leukemia" }\end{array}$ & 15 & 1 \\
\hline Google scholar & $\begin{array}{l}\text { "PEG-asp" OR "pegylated asparaginase" OR "pegylated (PEG)-ASP” OR } \\
\text { "polyethylene glycol conjugated asparaginase" OR "pegaspargase" AND } \\
\text { "Escherichia coli L-asparaginase OR E. coli L-asp" OR "native L-asparaginase } \\
\text { (L-asp)" AND "hypersensitivity" OR “allergic reactions" AND "childhood } \\
\text { acute lymphoblastic leukemia" }\end{array}$ & 11 & 2 \\
\hline
\end{tabular}

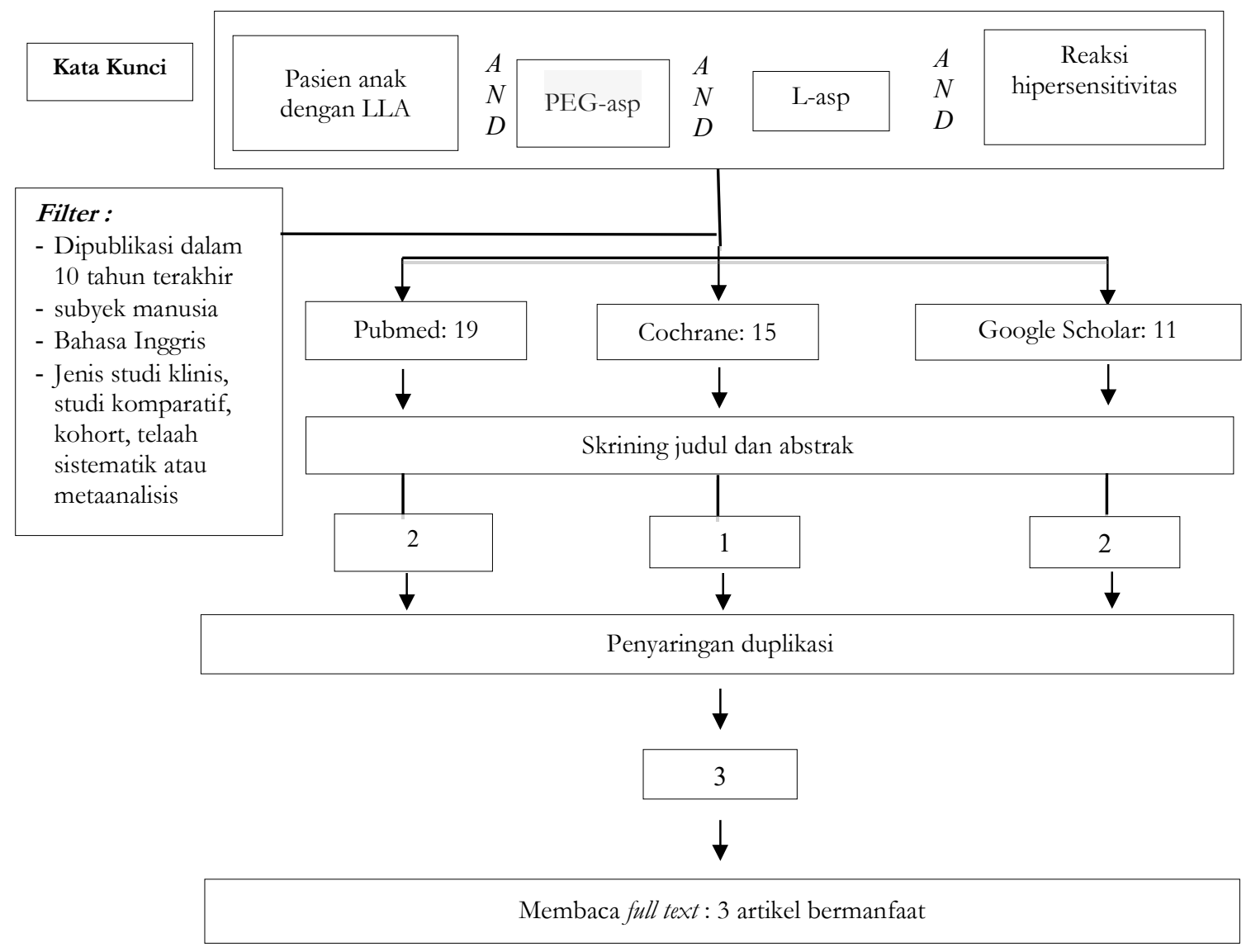

Gambar 1. Diagram alur pemilihan literatur 
Ketiga, studi hanya menilai reaksi-hipersensitivitas secara klinis sehingga kemungkinan terjadinya silent inactivation tidak diketahui dan tidak dijelaskan derajat keparahan reaksi hipersensitivitas yang terjadi. Keempat, luaran yang dinilai hanya jangka pendek.

Studi kedua adalah studi komparatif oleh Liu $\mathrm{dkk}^{11}$ yang melihat reaksi hipersensitivitas dengan menilai kadar antibodi terhadap PEG-asp, L-asp dan terhadap komponen polyethylene glycol (PEG). Studi ini merupakan bagian dari studi klinis acak St. Jude XVI yang memberikan PEG-asp IV sebagai regimen kemoterapi pada anak dengan LLA dan dibandingkan dengan studi klinis acak St. Jude Total $\mathrm{XV}$ yang menggunakan regimen L-asp IM. Pemeriksaan antibodi dilakukan saat awal masuk obat (hari ke-1 dan ke-5) diikuti 4-6 kali pemeriksaan selama fase induksi, konsolidasi dan saat fase pemeliharaan. Bila terjadi reaksi alergi maka pemeriksaan antibodi L-asp dikerjakan di luar jadwal pemeriksaan rutin. Reaksi alergi dikalsifikasikan berdasarkan kriteria National Cancer Institute Common Terminology Criteria for Adverse Events version 3.0.

Hasil studi oleh Liu dkk ${ }^{11}$ menunjukkan bahwa angka kejadian reaksi hipersensitivitas pada kelompok PEG-asp lebih rendah dibandingkan kelompok L-asp $(13,5 \% \%$ vs $41 \%, \mathrm{p}<0,005)$. Namun, derajat beratnya reaksi alergi lebih berat kelompok PEG-asp dibandingkan L-asp (derajat tiga atau empat sebanyak 9,7\% pada kelompok PEG-asp dan 5,9\% pada kelompok L-asp, $\mathrm{p}=0,028)$. Di antara pasien yang tidak menimbulkan gejala alergi, terdapat 89/410 (22\%) subyek pada kelompok L-asp yang memiliki antibodi (silent inactivation) dan 107/598 (18\%) subyek pada kelompok PEG-asp $(\mathrm{p}=0,13)$. Studi ini menganalisis terbentuknya antibodi pada kelompok PEG-asp dapat disebabkan antibodi terhadap komponen PEG (antiPEG) saja atau anti-L-asp atau keduanya. Didapatkan 618/5.369 (11,5\%) sampel dari 598 subyek pada kelompok PEG-asp yang positif terhadap anti-PEGasp Di antara sampel yang positif tersebut, 96 (15,5\%) sampel positif untuk kedua anti-PEG dan anti-L-asp, $495(80,1 \%)$ sampel positif hanya anti-PEG dan sebanyak $9(1,5 \%)$ sampel positif hanya terhadap L-asp. Sebagian besar reaksi alergi terjadi saat fase reinduksi atau fase pemeliharaan.

Studi oleh Liu $\mathrm{dkk}^{11}$ juga menilai kadar asparaginase pada pasien dengan serum antibodi positif. Selama fase induksi, tidak ada hubungan antara kadar asparaginase dan status antibodi, tetapi terdapat hubungan di fase lanjutan setelah minggu ke-7 $\left(\mathrm{n}=495 ; \mathrm{p}=5 \times 10^{-6}\right.$ untuk anti-PEG-asp; $\mathrm{p}=1,2 \times 10^{-8}$ untuk anti-L-asp; dan $p=7,5 \times 10^{-6}$ untuk anti-PEG). Kelompok dengan anti-L-asp positif memiliki efek menurunkan aktivitas asparaginase lebih tinggi di bandingkan anti-PEG-asp $(\mathrm{p}=0,032)$.

Studi ketiga adalah studi acak terkontrol oleh Place $\mathrm{dkk}^{12}$ yang membandingkan toksisitas, aktivitas serum asparaginase dan efektivitas dari PEG-asp IV dengan L-asp IM yang diberikan pada fase pasca-induksi pada anak dengan LLA yang baru terdiagnosis. Studi ini juga mengukur kecemasan dan nyeri yang dilaporkan pasien atau orangtua saat diberikan terapi dengan mengukur PedsQL. Kriteria inklusi adalah semua pasien anak usia 0-18 tahun yang baru terdiagnosis LLA dan belum mendapat terapi kecuali steroid kurang dari satu minggu atau terapi radiasi emergensi untuk massa mediastinum. Pasien diberikan terapi protokol fase induksi (32 hari) sesuai dengan risiko stratifikasi awal dengan pemberian satu kali PEG-asp IV di hari ketujuh. Setelah fase induksi selesai, dilakukan stratifikasi risiko final dengan melihat hasil minimal residual disease (MRD) dan sitogenetik. subyek yang mengalami remisi kemudian dirandomisasi untuk mendapat PEG-asp IV $2.500 \mathrm{IU} / \mathrm{m}^{2}$ setiap dua minggu sekali sebanyak 15 dosis atau mendapat L-asp IM $25.000 \mathrm{IU} / \mathrm{m}^{2}$ setiap minggu sebanyak 30 dosis. Serum asparaginase diperiksa pada hari ke-4, 11, 18 dan 25 setelah dosis pertama PEG-asp IV di fase induksi kemudian pada minggu ke-5, 11, 17, 23 dan 29 setelah fase induksi.

Reaksi hipersensitivitas pada pemberian pertama PEG-asp di minggu pertama adalah 7/551 (1\%) subyek. Sebanyak 463 subyek dirandomisasi (231 subyek mendapat L-asp IM dan 232 subyek mendapat PEG-asp). Karakteristik awal kedua kelompok terlihat tidak berbeda bermakna. Pada studi ini reaksi alergi dan derajat beratnya reaksi alergi pada kedua kelompok tidak berbeda bermakna (12\% pada kelompok PEGasp IV dan 9\% pada kelompok L-asp IM dengan nilai $\mathrm{p}=0,36)$. Median waktu terjadinya reaksi alergi pada kelompok PEG-asp lebih awal yaitu setelah dosis pertama di fase pasca-induksi dibandingkan kelompok L-asp, yaitu setelah lima dosis di fase pasca-induksi. Kadar asparaginase serum bertahan pada dosis terapi $(>0,1 \mathrm{IU} / \mathrm{mL})$ setelah pemberian PEG-asp IV dalam waktu yang lama, yaitu $96 \%$ pada hari ke- 11 dan turun menjadi $87 \%$ setelah hari ke-18. Perbandingan kadar asparaginase pada kelompok PEG-asp IV lebih tinggi dibandingkan kelompok L-asp IM $(\mathrm{p}<0,0001)$ sejak 
minggu kelima sampai dengan minggu ke-29. Event free survival (EFS) dan overall free survival (OFS) selama lima tahun pada kedua kelompok tidak berbeda bermakna (90\% dan 96\% pada kelompok PEG-asp, 89\% dan $94 \%$ pada kelompok L-asp, p>0,05). Pada analisis posthoc terlihat bahwa EFS lima tahun pada subyek yang mengalami reaksi alergi, kelompok PEG-asp memiliki EFS lebih tinggi, yaitu 91\% (IK 79-99\%) dibandingkan kelompok L-asp 79\% (IK 61-97\%) dengan nilai $\mathrm{p}=0,22$. Tambahan data yang di dapat dari studi Place $\mathrm{dkk}^{12}$ adalah adanya tingkat kecemasan yang lebih tinggi dilaporkan orangtua dan pasien pada kelompok yang mendapat L-asp IM. Namun, data tidak disajikan pada artikel yang dipublikasi dan dibutuhkan penelitian lebih lanjut yang khusus membahas perbandingan kualitas hidup pasien.

Tabel 3. Telaah kritis (1)

\begin{tabular}{|c|c|}
\hline Artikel & Dai dkk ${ }^{10}$ \\
\hline $\begin{array}{l}\text { Desain } \\
\text { Penelitian }\end{array}$ & Telaah sistematik dari uji klinis acak terkontrol \\
\hline Tingkatan bukti & $1 \mathrm{a}$ \\
\hline PICO & \\
\hline $\mathrm{P}$ & Pasien anak usia 0-18 tahun di China dengan LLA \\
\hline I & Pemberian terapi PEG-asp dalam kombinasi obat kemoterapi LLA \\
\hline $\mathrm{C}$ & Pemberian terapi L-asp dalam kombinasi obat kemoterapi LLA \\
\hline $\mathrm{O}$ & Efikasi dan keamanan PEG-asp dibandingkan L-asp \\
\hline Validity & $\begin{array}{l}\text { PICO } \\
\text { Pertanyaan klinis tergambar pada abstrak dan akhir paragraf pendahuluan. } \\
\text { Missed relevant studies } \\
\text { Penelusuran dilakukan melalui pangkalan data PubMed, Cochrane, China National Knowledge } \\
\text { Infrastructure (CNKI), WanFang Data, and VIP Chinese periodical service platform. Referensi dari studi } \\
\text { yang didapat juga dicari dan ditambahkan ke daftar studi yang relevan. } \\
\text { Kriteria inklusi } \\
\text { Semua uji klinis acak dengan subyek anak China dengan LLA berusia 0-18 tahun. Intervensi } \\
\text { menggunakan PEG-asp dengan pembanding L-asp sebagai kontrol. Setiap studi melaporkan salah satu } \\
\text { luaran yaitu CR, OS, reaksi hipersensitivitas, gangguan gastrointestinal dan gangguan koagulasi. Penapisan } \\
\text { studi dilakukan oleh dua orang secara independen. } \\
\text { Validitas dari studi yang dipilih } \\
\text { Peneliti melakukan analisis risiko bias pada semua studi yang relevan menggunakan Cochrane risk-of-bias } \\
\text { tool. Hasil tiap studi disajikan dalam tabel. Terdapat risiko tinggi bias pada tiga dari lima belas studi yang } \\
\text { relevan. } \\
\text { Hasil serupa antar studi } \\
\text { Studi yang dilibatkan homogen (nilai p }>0.10 \text { dan } \mathrm{I}^{2}<50 \% \text { ) } \\
\text { Kesimpulan: sahih }\end{array}$ \\
\hline Importance & $\begin{array}{l}\text { Efektivitas: CR kelompok PEG-asp dibandingkan L-asp adalah } 76 \% \text { dan } 75 \%(\mathrm{RR}=1,01 ; \mathrm{IK} 95 \% 0,96- \\
\text { 1,08; } \mathrm{p}=0,64) \text {. ORR PEG-asp dibandingkan L-asp adalah } 95 \% \text { dan } 92 \%(\mathrm{RR}=1,03 ; \mathrm{IK} 95 \% 1,00-1,06 \text {; } \\
\mathrm{p}=0,06) \text {. } \\
\text { Reaksi hipersensitivitas: Pada kelompok PEG-asp dibandingkan L-asp }(14,3 \% \text { vs } 30,7 \%, \mathrm{RR}=0,45, \mathrm{IK} \\
\text { 95\% 0,27 - 0,75 dan p =0,02) } \\
\text { Kesimpulan: Tidak ada perbedaan efektivitas terapi antara PEG-asp dan L-asp. Angka kejadian reaksi } \\
\text { hipersensitivitas pada kelompok PEG-asp lebih rendah secara bermakna. }\end{array}$ \\
\hline Applicability & $\begin{array}{l}\text { Apakah sama dengan kondisi pasien? Ya } \\
\text { Apakah intervensi bisa dilakukan di tempat saya bekerja? Ya bila sediaan telah tersedia } \\
\text { Apakah keuntungan lebih besar dibandingkan kerugian? Ya }\end{array}$ \\
\hline
\end{tabular}




\section{Telaah kritis}

Ketiga artikel relevan tersebut kemudian ditelaah kritis dengan hasil seperti tertera pada Tabel 3, 4, dan 5.

\section{Pembahasan}

L-asparaginase adalah suatu enzim yang diisolasi dari bakteri dan menjadi salah satu agen kemoterapi yang efektif dalam mengeradikasi sel blas di fase induksi atau reinduksi/intensifikasi. Kendala yang ditemukan dalam pemberian L-asp adalah tingginya angka kejadian reaksi hipersensitivitas, yaitu 30-70\%., ${ }^{14}$ Salah satu cara untuk mengurangi reaksi hipersensitivitas adalah dengan pemberian secara IM/subkutan dibandingkan pemberian IV (angka kejadian reaksi hipersentivitas 20-40\%). ${ }^{13}$ Namun, pemberian secara IM/subkutan dapat menyebabkan nyeri pada lokasi penyuntikan, pada dosis yang besar harus diberikan injeksi multipel, dan menimbulkan trauma pada pasien.

Pasien anak dengan LLA yang tidak mendapat terapi asparaginase secara optimal akibat efek samping yang ditimbulkan, alergi atau silent inactivation

Tabel 4. Telaah kritis (2)

\begin{tabular}{|c|c|}
\hline Artikel & Liu dkk ${ }^{11}$ \\
\hline $\begin{array}{l}\text { Desain } \\
\text { Penelitian }\end{array}$ & Kohort retrospektif \\
\hline \multicolumn{2}{|c|}{ Tingkatan bukti $2 \mathrm{~b}$} \\
\hline \multicolumn{2}{|c|}{$\mathrm{PICO}$} \\
\hline $\mathrm{P}$ & Pasien anak baru terdiagnosis LLA \\
\hline I & Pemberian terapi PEG-asp dalam kombinasi obat kemoterapi LLA \\
\hline $\mathrm{C}$ & Pemberian terapi L-asp dalam kombinasi obat kemoterapi LLA \\
\hline $\mathrm{O}$ & Reaksi hipersensitivitas dan kegunaan pemeriksaan antibodi untuk mendiagnosis alergi \\
\hline \multirow[t]{11}{*}{ Validity } & $\underline{\text { Randomisasi }}$ \\
\hline & $\begin{array}{l}\text { Randomisasi dilakukan pada masing-masing kelompok (membandingkan dua studi uji acak terkontrol) } \\
\text { Karakteristik subyek }\end{array}$ \\
\hline & $\begin{array}{l}\text { Karakteristik kedua kelompok tidak berbeda tersaji dalam tabel karakteristik subyek pada data lampiran } \\
\text { artikel. } \\
\text { Perlakuan }\end{array}$ \\
\hline & Kedua kelompok diperlakukan sama selain intervensi yang diberikan \\
\hline & Analisis \\
\hline & Analisis dilakukan pada seluruh subyek \\
\hline & Penyamaran \\
\hline & Tidak memungkinkan dilakukan penyamaran, terapi diberian sesuai protokol \\
\hline & Pemantauan \\
\hline & 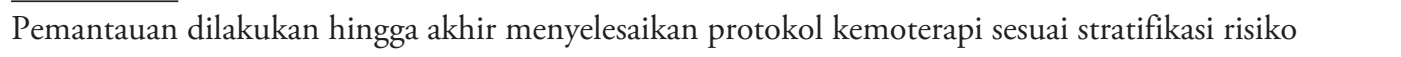 \\
\hline & Kesimpulan: sahih \\
\hline \multirow[t]{6}{*}{ Importance } & Reaksi hipersensitivitas pada kelompok PEG-asp $=13 \%$ \\
\hline & Reaksi hipersensitivitas pada kelompok L-asp = $41 \%$ \\
\hline & Relative Risk $(\mathrm{RR})=0,3$ \\
\hline & Absolute risk reduction $(\mathrm{ARR})=28 \%$ \\
\hline & Number needed to treat $(\mathrm{NNT})=3,5$ \\
\hline & $\begin{array}{l}\text { Kesimpulan: Angka kejadian reaksi hipersensitivitas pada kelompok PEG-asp lebih rendah secara } \\
\text { bermakna dibandingkan kelompok L-asp. }\end{array}$ \\
\hline \multirow[t]{3}{*}{ Applicability } & Apakah sama dengan kondisi pasien? Ya \\
\hline & Apakah intervensi bisa dilakukan di tempat saya bekerja? Ya bila sediaan telah tersedia \\
\hline & Apakah keuntungan lebih besar dibandingkan kerugian? Ya \\
\hline
\end{tabular}


Tabel 5. Telaah kritis (3)

\begin{tabular}{|c|c|}
\hline Artikel & Place $^{12}$ \\
\hline $\begin{array}{l}\text { Desain } \\
\text { Penelitian }\end{array}$ & Uji klinis acak \\
\hline Tingkatan bukti & $1 \mathrm{~b}$ \\
\hline $\begin{array}{l}\text { PICO } \\
\text { P } \\
\text { I } \\
\text { C } \\
\mathrm{O}\end{array}$ & $\begin{array}{l}\text { Pasien anak baru terdiagnosis LLA } \\
\text { Pemberian terapi PEG-asp IV dalam kombinasi obat kemoterapi LLA } \\
\text { Pemberian terapi L-asp IM dalam kombinasi obat kemoterapi LLA } \\
\text { Toksisitas asparaginase dan efektivitas terapi }\end{array}$ \\
\hline Validity & $\begin{array}{l}\text { Randomisasi } \\
\text { Randomisasi dilakukan setelah seluruh subyek di fase induksi diterapi dengan PEG-asp IM, dengan } \\
\text { metode blok dan distratifikasi sesuai kategori stratifikasi risiko pada LLA } \\
\text { Karakteristik subyek } \\
\text { Karakteristik kedua kelompok tidak berbeda tersaji dalam tabel karakteristik subyek di Tabel } 1 . \\
\text { Perlakuan } \\
\text { Kedua kelompok diperlakukan sama selain intervensi yang diberikan } \\
\text { Analisis } \\
\text { Analisis intention-to-treat } \\
\text { Penyamaran } \\
\text { Tidak memungkinkan dilakukan penyamaran, terapi diberian sesuai protokol } \\
\text { Pemantauan } \\
\text { Pemantauan dilakukan hingga akhir menyelesaikan protokol kemoterapi sesuai stratifikasi risiko } \\
\text { Kesimpulan: sahih }\end{array}$ \\
\hline Importance & $\begin{array}{l}\text { Reaksi hipersensitivitas pada kelompok PEG-asp }=12 \% \\
\text { Reaksi hipersensitivitas pada kelompok L-asp }=9 \% \\
\text { Relative Risk }(\mathrm{RR})=1,33 \\
\text { Absolute risk reduction }(\mathrm{ARR})=3 \% \\
\text { EFS dan OFS lima tahun }=90 \% \text { dan } 96 \% \text { pada kelompok PEG-asp, } 89 \% \text { dan } 94 \% \text { pada kelompok } \\
\text { L-asp, } \mathrm{p}>0,05)\end{array}$ \\
\hline & $\begin{array}{l}\text { Kesimpulan: Tidak ada perbedaan efektivitas terapi antara PEG-asp dan L-asp. Angka kejadian reaksi } \\
\text { hipersensitivitas tidak berbeda antar kedua kelompok yang kemungkinan disebabkan saat fase induksi } \\
\text { diberikan PEG-asp. }\end{array}$ \\
\hline Applicability & $\begin{array}{l}\text { Apakah sama dengan kondisi pasien? Ya } \\
\text { Apakah intervensi bisa dilakukan di tempat saya bekerja? Ya bila sediaan telah tersedia } \\
\text { Apakah keuntungan lebih besar dibandingkan kerugian? Ya }\end{array}$ \\
\hline
\end{tabular}

memiliki luaran yang lebih rendah. Paparan terhadap asparaginase (sebagai protein antigen) dapat menyebabkan terbentuknya antibodi anti-asparaginase yang dapat menetralisir aktivitas enzim. Gejala dari reaksi hipersensitivitas dapat terjadi lokal pada lokasi penyuntikan sampai dengan gejala sistemik seperti anafilaksis. Selain itu, terdapat fenomena silent inactivation, yaitu suatu kondisi terbentuknya antibodi anti-asparaginase yang menyebabkan kadar serum asparaginase menurun, tetapi tidak menimbulkan gejala alergi. Makna klinis yang penting dalam hal ini adalah melanjutkan terapi dengan sediaan aspraginase yang sama pada pasien yang mengalami reaksi hipersensitivitas atau silent inactivation adalah membahayakan dan tidak efektif. ${ }^{14}$

Pegaspargase/PEG-asp adalah sediaan L-asp yang dikonjugasi dengan polyethylene glycol (PEG). Ikatan tersebut dapat menjaga aktivitas enzim dan 
menurunkan sifat imunogenik dari protein L-asp sehingga diharapkan dapat menurunkan risiko terjadinya reaksi hipersensitivitas. Berdasarkan studi Dai dkk ${ }^{11}$ dan Place $\mathrm{dkk}^{13}$ tampak bahwa tidak terdapat perbedaan efektivitas pada kelompok yang diterapi PEG-asp dan L-asp. Pada studi Place dkk, ${ }^{13}$ angka kesintasan lima tahun pada kelompok PEG-asp IV dibandingkan L-asp IM adalah 90\% dan 89\% ( $\mathrm{p}=0,58)$. Namun, pada post-hoc analisis subyek yang mengalami reaksi hipersensitivitas, EFS kelompok PEG-asp lebih tinggi dibandingkan kelompok L-asp walaupun tidak bermakna secara statistik ( $91 \%$ vs $79 \%, \mathrm{p}=0,22) .{ }^{12}$ $\mathrm{Hal}$ tersebut kemungkinan disebabkan oleh reaksi hipersensitivitas pada kelompok PEG-asp terjadi karena alergi terhadap komponen PEG bukan pada enzim asparaginase. Liu $\mathrm{dkk}^{11}$ mendapatkan bahwa lebih dari $80 \%$ sampel yang positif terhadap anti-PEG-asp hanya memiliki antibodi anti-PEG sehingga aktivitas enzim asparaginase tidak menurun. ${ }^{11}$

Pada dua studi terlihat bahwa reaksi hipersensitivitas yang ditimbulkan pada kelompok yang mendapat PEGasp lebih rendah dibandingkan L-asp. ${ }^{11,12}$ Sementara studi yang membandingkan PEG-asp IV dan L-asp IM menunjukkan bahwa tidak terdapat perbedaan reaksi hipersensitivitas pada kedua kelompok (12\% vs 9\%, $\mathrm{p}=0,36) .{ }^{13} \mathrm{Hal}$ tersebut kemungkinan disebabkan oleh seluruh subyek di fase induksi mendapat PEG-asp, randomisasi dilakukan setelah fase induksi dan reaksi hipersensitivitas yang dinilai post-induksi. Berdasarkan hal itu, disebutkan bahwa penggunaan PEG-asp di fase induksi kemungkinan dapat mencegah terjadinya reaksi hipersensitivitas pada fase post induksi terutama pada kelompok yang mendapat L-asp IM. ${ }^{12}$

Pada studi Place $\mathrm{dkk}^{12}$ disebutkan bahwa angka kejadian silent inactivation yang dinilai dari kadar aktivitas serum asparaginase di bawah kadar terapi pada L-asp adalah $20 \%$, sedangkan pada kelompok PEGasp hanya $3 \%$. Pada studi Liu $\mathrm{dkk}^{11}$ didapatkan $22 \%$ subyek pada kelompok L-asp dan $18 \%$ subyek pada kelompok PEG-asp mengalami silent hypersensitivity (tidak ada klinis alergi dengan antibodi positif). Adanya antibodi terhadap PEG-asp belum tentu menyebabkan silent inactivation karena masih mungkin antibodi yang terbentuk hanya terhadap komponen PEG dan tidak memengaruhi aktivitas enzim asparaginase. Oleh sebab itu, pemantauan rutin terhadap kadar enzim asparaginase direkomendasikan untuk mengetahui kejadian silent inactivation. Apabila dalam dua kali pemeriksaan pada dua waktu yang berbeda kadarnya lebih rendah dari kadar terapeutik, maka perlu dipikirkan telah terjadi silent inactivation. Pemeriksaan ini sudah dikerjakan di beberapa negara maju seperti Eropa dan Amerika, tetapi ketersediaan alat masih terbatas dan biayanya yang cukup mahal. Pemeriksaan antibodi anti-asparaginase dapat dipertimbangkan, tetapi sampai saat ini pemeriksaan tersebut masih dalam tahap penelitian dan belum ada produk komersial yang dipasarkan. ${ }^{14}$

Sediaan PEG-asp memiliki waktu paruh obat yang lebih panjang dibandingkan L-asp, yaitu 5,5-7 hari untuk PEG-asp dan 8-30 jam untuk L-asp. Pada studi Place dkk, ${ }^{12}$ pemberian satu kali PEG-asp IV di fase induksi dapat mempertahankan kadar serum asparaginase dalam kadar terapeutik sebanyak 96\% pada hari ke-11 dan $87 \%$ pada hari ke- $18 .{ }^{12}$ Oleh sebab itu, PEG-asp dapat diberikan setiap dua minggu sekali, sedangkan L-asp diberikan setiap dua-tiga kali seminggu. Dengan frekuensi penyuntikan yang lebih sedikit maka angka kunjungan ke rumah sakit berkurang dan dapat mengurangi beban biaya kesehatan. ${ }^{10}$ Pada studi Dai dkk, ${ }^{10}$ kelompok yang mendapat PEG-asp secara bermakna menunjukkan frekuensi kunjungan ke RS lebih sedikit dan lama masa perawatan lebih rendah $(p<0,00001)$. Suatu studi yang menilai costeffectiveness PEG-asp dibandingkan L-asp di Inggris mendapatkan bahwa PEG-asp sebagai multi-agen kemoterapi pada anak dengan LLA lebih efisien. Studi tersebut mempertimbangkan siklus terapi, reaksi hipersensitivitas yang terjadi dan kebutuhan untuk pergantian regimen ke lini kedua. Diperlukan penelitian lebih lanjut untuk menilai cost-effectiveness PEG-asp dibandingkan L-asp karena kebijakan dan protokol di setiap negara bisa berbeda.

Dua artikel pada studi kasus berbasis bukti ini menggunakan PEG-asp secara IV. Pada artikel ketiga, mereka menilai level kecemasan pasien dan atau orangtua terhadap pemberian PEG-asp IV dibandingkan L-asp IM, hasilnya ditemukan level kecemasan yang lebih rendah pada kelompok PEG-asp IV. Beberapa studi telah dilakukan untuk membanding PEG-asp IV dan IM, didapatkan bahwa efek samping reaksi hipersensitivitas pemberian satu dosis PEG-asp IV pada bulan pertama fase induksi tidak berbeda bermakna dengan pemberian IM, dan aktivitas serum asparaginase dapat dipertahankan berada pada level $\geq 0,1$ $\mathrm{IU} / \mathrm{mL}$ selama dua minggu. ${ }^{12}$, 


\section{Kesimpulan}

Reaksi hipersensitivitas atau silent inactivation pada penggunaan L-asp lebih tinggi dibandingkan dengan PEG-asp. Hal tersebut dapat menyebabkan obat tidak efektif dan memengaruhi luaran terapi. Oleh sebab itu, penggunaan PEG-asp sebagai lini pertama terapi asparaginase dapat dipertimbangkan pada protokol kemoterapi pasien anak dengan LLA di Indonesia.

\section{Daftar pustaka}

1. Medawar CV, Mosegui GB, Vianna CMM, da'Costa TM. PEG-asparaginase and native Escheria coli L-asparaginase in acute lymphoblastic leukemia in children and adolescents: a systematic review. Hematol Transfus Cell Ther 2019;42:2020.

2. OECD. Survival and mortality for leukaemia in children. Dalam: Health at a Glance 2017: OECD Indicators.Paris. OECD Publishing; 2017.h.126-7.

3. Murti Andriastuti. Respons steroid sebagai faktor prognostik kesintasan leukemia limfoblastik akut pada anak: tinjauan khusus pada penilaian imunofenotiping, sitogenetik, molekular, dan minimal residual disease, [disertasi]. Jakarta: Fakultas Kedokteran Universitas Indonesia, 2015.

4. Mulatsih S, Sumadiono, Sutaryo, Purwanto. The result of treating children's acute lymphoblastic leukemia (LLA) in Dr. Sardjito Hospital with WK-LLA Protocol 1999-2002. Buletin Ilmu KesehatanAnak FK UNAIR 2005;17:808-19.

5. Mondelaers V, Bauters T, Moerloose BD, Benoit Y. PEGasparaginase in the treatment of childhood acute lymphoblastic leukemia. Belg J Hematol 2013;4:138-43.

6. Silverman LB, Gelber RD, Dalton VK, Asselin BL, Barr $\mathrm{RD}$, Clavell LA. Improved outcome for children with acute lymphoblastic leukemia: results of Dana-Farber Consortium Protocol 91-01. Blood 2001;97:1211-8.

7. Heo YA, Syed YY, Keam SJ. Pegasparginase: A review in acute lymphoblastic leukemia. Drugs 2019;79: 67-77.

8. Battistel AP, Rocha BS, Santos MT, Daudt LE, Michalowski MB. Allergic reactions to asparaginase: Retrospective cohort study in pediatric patients with acute lymphoid leukemia. Hematol Transfus Cell Ther 2020;31:1-6.

9. Santos AC, Land MG, da'Silva NP, Santos KO, Dellamora EC. Reactions related to asparaginase infusion in a 10-year retrospective cohort. Rev Bras Hematol Hemoter 2017;39:33742.

10. Dai Z, Huang Y, Lu Y. Efficacy and safety of PEGasparaginase versus E. coli L-asparaginase in Chinese children with acute lymphoblastic leukemia: A meta-analysis. Authorea 2020;10:1-11.

11. Liu Y, Smith CA, Panetta JC, dkk. Antibodies predict pegaspargase allergic reactions and failure of rechallange. $\mathrm{J}$ Clin Oncol 2019;37:2051-61.

12. Place AE, Stevenson K, Harris MH, dkk. Intravenous pegylated asparaginase versus intramuscular native Escheria coli L-asparaginase in newly diagnosed childhood acute lymphoblastic leukaemia (DFCI 05-001): a randomised, openlabel phase 3 trial. Lancet Oncol 2015;16:1677-90.

13. MacDonald T, Kulkarni K, Bernstein M, Fernandez CV. Allergic reactions with intravenous compared with intramuscular pegasparaginase in children with high-risk acute lymphoblastic leukemia: A population-based study from the Maritimes, Canada. J Pediatr Hematol Oncol 2016;38:341-4.

14. Sluis IM, Vrooman LM, Baruchel A, dkk. Consensus expert recommendations for identification and management of asparaginase hypersensitivity and silent inactivation. Haemotologica 2016;100:279-85.

15. Hu Xingdi, Wildman KP, Basu S, Lin PL, Rowntree C, Saha $\mathrm{V}$. The cost-effectiveness of pegasparaginase versus native asparaginase for first line treatment of acute lymphoblastic leukemia: a UK-based cost-utility analysis. Health Econ Rev 2019;9:1-13.

16. Angiolillo AL, Schore RJ, Devidas M. Pharmacokinetic and pharmacodynamic properties of calaspargase pegol Escherichia coli L-asparaginase in the treatment of patients with acute lymphoblastic leukemia: results from Children's Oncology Group Study ALL07P4. J Clin Oncol 2014;32:3874-82. 